$\begin{gathered}\text { Науковий вісник НЛтУ України } \\ \text { Scientific Bulletin of UNFU } \\ \text { https://nv.nltu.edu.ua }\end{gathered}$
$\begin{aligned} & \text { https://doi.org/10.36930/40300206 } \\ & \text { Article received 26.02.2020 p. } \\ & \text { Article accepted 04.06.2020 p. }\end{aligned}$
ISSN 1994-7836 (print)
UDC 634.51:581.143.28[282.485:477]

О. М. Абоімова

Національний ботанічний сад ім. М. М. Гришка, НАН Украӥни, м. Київ, Украӥна

\title{
ОСОБЛИВОСТІ СЕЗОННОГО РОЗВИТКУ ВИДІВ РОДУ JUGLANS L. В УМОВАХ КИЇВСЬКОГО ПОЛІССЯ
}

Досліджено особливості сезонного розвитку рослин роду Juglans в умовах Лісостепу України у 2015-2018 рр. Встановлено, що умовах Лісостепу першим починають вегетувати рослини зі Східноазійської флористичної області (J. mandshurica) $3.04^{ \pm 4,5}$. За період фенологічних спостережень спочатку фаза цвітіння відбувалась у Східноазійських видів (J. mandshurica) $07.05^{ \pm 6,1}$ за суми ефективних температур $361,1^{ \pm 32,2}$. Рослини з Мадреанської флористичної області починають цвісти пізніше від усіх дослідних рослин - $25.05^{ \pm 6,1}$ (J. major) за суми ефективних температур 407,2 $2^{ \pm 12,8}$. Завершення цвітіння спочатку спостерігається у рослин зі Східноазійської флористичної області (J. mandshurica) $19.05^{ \pm 6,2}$ за суми ефективних температур $401,2^{ \pm 65,1}$. Найпізніше з-поміж усіх дослідних видів завершується фаза цвітіння у рослин з Мадреанської флористичної області (J. microcarpa) $08.06^{ \pm 6,5}$ за суми ефективних температур $496,1^{ \pm 24,4}$. Достигання плодів спочатку відбувається у рослин Східноазійської флористичної - наприкінці третьої декади серпня (J.mandshurica) за суми ефективних температур $+2430 \pm 5,1{ }^{\circ} \mathrm{C}$. Достигання плодів у рослин з Атлантико-Північноамериканської флористичної області відбувається на початку другої декади вересня - $12.09^{ \pm 3,3}$ (J. nigra) за суми ефективних температур $2675^{ \pm 6,4}{ }^{\circ} \mathrm{C}$. У рослин з Мадреанської флористичної області плоди достигають на початку третьої декади вересня. Початок осіннього забарвлення листків спочатку зафіксовано у рослин зі Східноазійської (Японо-Китайської) флористичної області $28.08^{ \pm 9,5}$ (J.mandshurica) за суми ефективних температур $2430^{ \pm 6,5}{ }^{\circ} \mathrm{C}$. Найпізніше, з усіх дослідних видів, ця фаза настає у рослин з Мадреанської флористичної області $(J$. major) $15.09^{ \pm 6,5}$ за суми ефективних температур $2705,1^{ \pm 60,4}$. Листопад (кінець вегетаціі) спочатку спостерігається у рослин Східноазійської (Японо-Китайської) флористичної області, в середньому $12.09^{ \pm 3,7}$ за суми ефективних температур $+2675,4^{ \pm 105,65 \circ} \mathrm{C}$. У рослин Мадреанської флористичної області листопад настає пізніше від усіх дослідних видів в середньому $22.09^{ \pm 6,7}$ за суми ефективних температур +2780 . 3'ясовано, що кліматичні умови району інтродукції сприятливі для масового вирощування цих рослин. Тривалість вегетаційного періоду рослин Juglans становить 173-195 днів, що відповідає тривалості вегетаційного періоду в регіоні інтродукції.

Ключові слова: фенологічні фази; сума ефективних температур; вегетативні органи; генеративні органи; вегетаційний період.

Вступ. Ріст і розвиток інтродуцентів у районах їх поширення визначають багаторічними дослідженнями проходження рослинами фенологічних фаз розвитку впродовж вегетаційного періоду, терміни яких характеризують їх відповідність кліматичним умовам вирощування [14]. Вивчення сезонних ритмів росту і розвитку рослин, особливо в умовах інтродукції, має важливе значення для оцінення успішності їх акліматизації [10]. Фенологічні спостереження за рослинами роду Juglans L. в колекції НБС ім. М. М. Гришка НАН України здійснив Б. К. Гришко-Богменко [5] майже 60 років тому. Тому, завданнями нашого дослідження є подальше вивчення сезонного розвитку цих інтродуцентів для порівняння результатів дослідження 3 раніше отриманими даними.

Сучасні дослідження клімату показують, що середньорічна температура зросла на $0,6-0,7{ }^{\circ} \mathrm{C}$ за період інструментальних спостережень 31850 по 2000 pp. [9, 2]. Аналогічними є результати розрахунків на глобальних кліматичних моделях, що беруть участь у програмі порівняння сценаріїв глобального кліматичного потепління, здійснюваною міжурядової групою експертів зі зміни клімату (IPCC), і в міжнародній програмі порівняння результатів модельних реконструкцій палеоклімату $[6,11]$ та ін.

Проаналізувавши літературні джерела, з'ясовано, що даних про сучасний сезонний розвиток рослин роду Juglans в Лісостепу України немає, тому є потреба у вивченні сезонних ритмів цих дослідних рослин в умовах кліматичних змін.

Об'єкт дослідження - рослини роду Juglans L. в колекції НБС ім. М. М. Гришка НАН України (у відділі дендрології та акліматизації плодових рослин). Назви рослин наведено за електронним ресурсом The Plant List [11] з доповненнями за World Plant (north america's largest database, 2019). Тепер колекція, створення якої розпочато з 1949 р., складається із семи видів, одного різновиду й однієї форми, природні ареали яких належать до чотирьох флористичних областей: АтлантикоПівнічноамериканської - J. cinerea L., J. nigra L., Мад-

\section{Інформація про автора:}

Абоімова Олександра Миколаївна, аспірант, пров. інженер, відділ акліматизації плодових рослин.

Email: aboimovaaleksandra@gmail.com; https://orcid.org/0000-0002-3622-4669

Цитування за ДСту: Абоімова О. М. Особливості сезонного розвитку видів роду Juglans L. в умовах Київського Полісся. Науковий вісник НЛТУ України. 2020, т. 30, № 2. С. 33-37.

Citation APA: Aboimova, O. M. (2020). Features of seasonal development of species of the genus Juglans L. in the conditions of the Kyiv Polissya. Scientific Bulletin of UNFU, 30(2), 33-37. https://doi.org/10.36930/40300206 
реанської - J. major (Torr.) A. Heller, J. microcarpa Berland. (у колекцію НБС рослини завезені під назвою, яку тепер вважають синонімом - J. rupestris Engelm. ex Torr.), Східноазійської (Японо-Китайської) - J. ailantifolia Carriere (у колекцію НБС рослини завезені під назвою, яку тепер вважають синонімом - J. sieboldiana Maxim.); J. ailantifolia var. cordiformis (Makino) Rehder (y колекцію НБС рослини завезені під назвою, яку тепер вважають синонімом - J. cordiformis Maxim., у літературі поширений й інший синонім - J. subcordiformis Dode), J. mandshurica Maxim.; Ірано-Туранської- J. regia L. (типові рослини та окрема колекція рослин скороплідної форми - J. regia f. fertillis Petz et Kirch.).

Предмет дослідження - методи і засоби визначення особливостей сезонного розвитку видів роду Juglans в умовах Київського Полісся.

Мета дослідження - дослідити сезонні ритми розвитку рослин роду Juglans в умовах Київського Полісся; визначити відмінності сучасної тривалості вегетаційного періоду і попередніх років.

Наукова новизна проведених досліджень полягає у тому, що вперше були вивченні особливостей сезонного розвитку рослин роду Juglans з різних флористичних областей порівняно з раніше отриманими даними попередніх спостережень, здійснених в умовах Київського Полісся. 3 огляду на істотні зміни глобального клімату, багаторічні дослідження сезонного розвитку інтродукованих рослин мають вагоме теоретичне і практичне значення. Дані багаторічних спостережень сезонного розвитку інтродуцентів можуть істотно відрізнятись під впливом глобального кліматичного потепління. Отже, аналіз отриманих результатів може дати відповідь на питання доцільності інтродукції дослідних рослин.

Матеріал і методи дослідження. Фенологічні спостереження за рослинами роду Juglans здійснювали у 2015-2018 pр. за методикою, рекомендованою для ботанічних садів [8, 12], на території Ботанічного саду ім. М. М. Гришка НАН України та у Голосіївських лісових насадженнях. Відстежували такі фази розвитку: набря- кання і розкривання вегетативних бруньок; набрякання і розкривання генеративних бруньок; початок росту пагонів; цвітіння; формування i достигання плодів; завершення росту пагонів; початок осіннього забарвлення листків; листопад. У процесі фенологічних спостережень за рослинами фіксували масове настання фенофаз (не менше ніж у 50 \% дослідних рослин); фазу цвітіння розподілили на два етапи: початок фенофази, коли вона проявлялася у 10 \% рослин, і кінець, коли для понад $90 \%$ рослин вона завершилася. Дати настання кожної фенофази зіставляли із сумою ефективних температур $\left(>5^{\circ} \mathrm{C}\right)$. Спостереження проводили (березеньлистопад) 2 рази на тиждень, а з липня - один раз на 56 діб. Календарні дати переводили в безперервний числовий ряд від 1 березня. За отриманими середніми багаторічними даними вираховували тривалість фенофази та будували феноспектр. Статистичне оброблення даних виконували відповідно до рекомендацій Г. М. Зайцева $[4,15]$. Урожайність визначали за шкалою Каппера [7].

Результати дослідження та їх обговорення. Дані щодо проходження фенологічних фаз росту і розвитку вегетативних органів представників роду Juglans наведено в табл. 1, а генеративних - у табл. 2.

Проходження фенологічних фаз пов'язували із сумами ефективних температур (більше $+5^{\circ} \mathrm{C}$ ). За період (2015-2018 рр.) фенологічних спостережень рослин роду Juglans набрякання вегетативних бруньок (початок вегетації) у рослин Східноазійської (Японо-Китайської) флористичної області раніше від усіх спостерігається у $J$. mandshurica $\left(3.04^{ \pm 4,5}\right)$ за суми ефективних температур $+62,4^{ \pm 3,5 \circ} \mathrm{C}$. Розкривання вегетативних бруньок зафіксовано у J.mandshurica $11.04^{ \pm 6,3}$ за суми ефективних температур $+192,1^{ \pm 4,4 ~} \mathrm{C}$.

У рослин Ірано-Туранської флористичної області набрякання вегетативних бруньок спостерігається $5.04^{ \pm 2,5}$ за суми ефективних температур $+71,1^{ \pm 7,5 \circ} \mathrm{C}(J$. regia). Розкривання вегетативних бруньок зафіксовано $24.04^{ \pm 3,4}$ за суми ефективних температур $264,7^{ \pm 10,5}$.

Табл. 1. Середні дати настання фенологічних фаз вегетативних органів рослин роду Juglans в умовах Лісостепу України та суми ефективних температур (2015-2018 рр.)

\begin{tabular}{|c|c|c|c|c|c|c|c|}
\hline \multirow{2}{*}{$\begin{array}{l}\text { Вид, різновид, } \\
\text { форма }\end{array}$} & \multicolumn{2}{|c|}{ Вегетативні бруньки } & \multicolumn{2}{|c|}{ Ріст пагонів } & \multirow{2}{*}{$\begin{array}{l}\text { Початок осіннього } \\
\text { забарвлення листків }\end{array}$} & \multirow{2}{*}{ Листопад } & \multirow{2}{*}{\begin{tabular}{|c|} 
Тривалість \\
вегетації, діб \\
\end{tabular}} \\
\hline & набрякання & розкривання & початок & завершення & & & \\
\hline \multicolumn{8}{|c|}{ Ірано-Туранська флористична область } \\
\hline J. regia & $\frac{* 6.04^{ \pm 8,5}}{72,8^{ \pm 7,3}}$ & $\frac{24.04^{ \pm 3,4}}{264,7^{ \pm 8,4}}$ & $\frac{24.05^{ \pm 5,3}}{438,2^{ \pm 21,1}}$ & $\frac{15.07^{ \pm 4,5}}{2186,4^{ \pm 75,8}}$ & $\frac{5.09^{ \pm 3,5}}{2606,2^{ \pm 85,0}}$ & $\frac{22.09^{ \pm 3,7}}{2675,4^{ \pm 105,6}}$ & $183^{ \pm 6,3}$ \\
\hline J. regiaf.fertillis & $\frac{5.04^{ \pm 2,5}}{71,1^{ \pm 7,5}}$ & $\frac{27.04^{ \pm 4,5}}{350,1^{ \pm 6,5}}$ & $\frac{23.05^{ \pm 6,2}}{403,2^{ \pm 3,2}}$ & $\frac{20.06^{ \pm 3,5}}{1375,2^{ \pm 25,5}}$ & $\frac{09.09^{ \pm 3,5}}{2650,4^{ \pm 75,1}}$ & $\frac{15.09^{ \pm 7,1}}{2700,6^{ \pm 55,5}}$ & $187^{ \pm 6,6}$ \\
\hline \multicolumn{8}{|c|}{ Східноазійська (Японо-Китайська) флористична область } \\
\hline J. mandshurica & $\frac{3.04^{ \pm 4,5}}{62,4^{ \pm 3,5}}$ & $\frac{11.04^{ \pm 6,3}}{192,1^{ \pm 4,4}}$ & $\frac{19.05^{ \pm 6,2}}{401,2^{ \pm 65,1}}$ & $\frac{28.07^{ \pm 3,1}}{2300,2^{ \pm 27,5}}$ & $\frac{28.08^{ \pm 9,5}}{2430^{ \pm 6,5}}$ & $\frac{12.09^{ \pm 3,7}}{2675,4^{ \pm 105,6}}$ & $173^{ \pm 4,3}$ \\
\hline J. ailantifolia & $\frac{7.04^{ \pm 6,5}}{77,1^{ \pm 8,5}}$ & $\frac{24.04^{ \pm 3,4}}{264,7^{ \pm 10,5}}$ & $\frac{20.05^{ \pm 6,13}}{397,6^{ \pm 30,2}}$ & $\frac{04.08^{ \pm 3,8}}{2280,2^{ \pm 32,8}}$ & $\frac{13.09^{ \pm 3,3}}{2668^{ \pm 35,4}}$ & $\frac{16.09^{ \pm 6,1}}{2700,6^{ \pm 27,3}}$ & $186^{ \pm 2,4}$ \\
\hline $\begin{array}{c}\text { J.ailantifolia var. } \\
\text { cordiformis }\end{array}$ & $\frac{5.04^{ \pm 3,5}}{71,1^{ \pm 5,5}}$ & $\frac{11.04^{ \pm 6,5}}{192,1^{ \pm 2,5}}$ & $\frac{21.05^{ \pm 6,1}}{398,2^{ \pm 31,1}}$ & $\frac{25.07^{ \pm 7,5}}{2270,0^{ \pm 17,5}}$ & $\frac{10.09^{ \pm 5,5}}{2661^{ \pm 9,5}}$ & $\frac{15.09^{ \pm 7,8}}{2745,5^{ \pm 24,5}}$ & $184^{ \pm 7,5}$ \\
\hline \multicolumn{8}{|c|}{ Атлантико-Північноамериканська флористична область } \\
\hline J. nigra & $\frac{15.04^{ \pm 7,0}}{370,4^{ \pm 11,3}}$ & $\frac{12.05^{ \pm 7,7}}{381,0^{ \pm 21,1}}$ & $\frac{28.05^{ \pm 6,3}}{430,1^{ \pm 41,3}}$ & $\frac{28.07^{ \pm 6,5}}{2222,2^{ \pm 22,7}}$ & $\frac{28.05^{ \pm 6,3}}{430,1^{ \pm 41,3}}$ & $\frac{12.09^{ \pm 3,3}}{2675^{ \pm 8,5}}$ & $187^{ \pm 2,3}$ \\
\hline J. cinerea & $\frac{06.04^{ \pm 6,1}}{75,3^{ \pm 34,2}}$ & $\frac{10.05^{ \pm 6,1}}{397,4^{ \pm 14,6}}$ & $\frac{29.05^{ \pm 6,3}}{434,5^{ \pm 4,4}}$ & $2 \frac{24.06^{ \pm 5,1}}{2200,1^{ \pm 13,1}}$ & $\frac{29.05^{ \pm 6,3}}{434,5^{ \pm 44,4}}$ & $\frac{30.09^{ \pm 8,7}}{2810^{ \pm 7,6}}$ & $190^{ \pm 8,3}$ \\
\hline \multicolumn{8}{|c|}{ Мадреанська флористична область } \\
\hline J. major & $\frac{10.04^{ \pm 3,7}}{120,1^{ \pm 8,5}}$ & $\frac{7.05^{ \pm 3,7}}{390,4^{ \pm 10,5}}$ & $\frac{06.06^{ \pm 6,4}}{471,1^{ \pm 12,2}}$ & $\frac{30.07^{ \pm 7,8}}{2330,1^{ \pm 7,1}}$ & $\frac{15.09^{ \pm 6,5}}{2705,1^{ \pm 60,4}}$ & $\frac{22.09^{ \pm 6,7}}{2780,4^{ \pm 77,2}}$ & $195^{ \pm 4,7}$ \\
\hline J. microcarpa & $\frac{08.04^{ \pm 10,5}}{88,1^{ \pm 9,6}}$ & $\frac{2.05^{ \pm 9,5}}{330,4^{ \pm 7,3}}$ & $\frac{08.06^{ \pm 6,5}}{496,1^{ \pm 24,4}}$ & $\frac{28.07^{ \pm 9,1}}{2300,2^{ \pm 3,2}}$ & $\frac{12.09^{ \pm 9,8}}{2675^{ \pm 6,2}}$ & $\frac{18.09^{ \pm 9,7}}{2745,5^{ \pm 17,5}}$ & $190^{ \pm 3,7}$ \\
\hline
\end{tabular}


Табл. 2. Середні дати настання фенологічних фаз генеративних органів рослин роду Juglans в умовах Київського Полісся та суми ефективних температур (2015-2018 pp.)

\begin{tabular}{|c|c|c|c|c|c|c|}
\hline \multirow{3}{*}{$\begin{array}{c}\text { Вид, різновид, } \\
\text { форма }\end{array}$} & \multicolumn{6}{|c|}{ Фенофази, час їх настання (чисельник) та суми ефективних температур (знаменник) } \\
\hline & \multicolumn{2}{|c|}{ Вегетативні бруньки } & \multicolumn{3}{|c|}{ Цвітіння } & \multirow{2}{*}{$\begin{array}{c}\text { Достигання } \\
\text { плодів }\end{array}$} \\
\hline & набрякання & розкривання & початок & мacoвe & завершення & \\
\hline \multicolumn{7}{|c|}{ Ірано-Туранська флористична область } \\
\hline J. regia & $\frac{06.04^{ \pm 5,5}}{71,1^{ \pm 7,5}}$ & $\frac{10.05^{ \pm 5,5}}{396,1^{ \pm 10,1}}$ & $\frac{15.05^{ \pm 6,1}}{384,2^{ \pm 2,3}}$ & $\frac{20.05^{ \pm 5,1}}{396,2^{ \pm 22,2}}$ & $\frac{24.05^{ \pm 5,3}}{438,2^{ \pm 21,1}}$ & $\frac{02.09^{ \pm 2,5}}{2560^{ \pm 77,5}}$ \\
\hline J. regiaf.fertillis & $\frac{06.04^{ \pm 5,5}}{76,4^{ \pm 13,1}}$ & $\frac{8.05^{ \pm 7,5}}{370,5^{ \pm 21,1}}$ & $\frac{12.05^{ \pm 6,1}}{370,3^{ \pm 13,3}}$ & $\frac{19.05^{ \pm 6,4}}{402,2^{ \pm 37,4}}$ & $\frac{23.05^{ \pm 6,2}}{403,2^{ \pm 3,2}}$ & $\frac{02.09^{ \pm 2,5}}{2560^{ \pm 0,5}}$ \\
\hline \multicolumn{7}{|c|}{ Східноазійська (Японо-Китайська) флористична область } \\
\hline J. mandshurica & $\frac{07.04^{ \pm 5,5}}{81,3^{ \pm 11,1}}$ & $\frac{03.05^{ \pm 7,1}}{350,1^{ \pm 21,1}}$ & $\frac{07.05^{ \pm 6,1}}{361,1^{ \pm 32,2}}$ & $\frac{12.05^{ \pm 6,6}}{384,4^{ \pm 43,4}}$ & $\frac{19.05^{ \pm 6,2}}{401,2^{ \pm 65,1}}$ & $\frac{28.08^{ \pm 8,3}}{2430^{ \pm 17,2}}$ \\
\hline J. ailantifolia & $\frac{06.04^{ \pm 3,5}}{74,1^{ \pm 14,6}}$ & $\frac{05.05^{ \pm 6,5}}{352,6^{ \pm 13,8}}$ & $\frac{10.05^{ \pm 6,1}}{368,7^{ \pm 41,1}}$ & $\frac{14.05^{ \pm 6,6}}{387,7^{ \pm 36,6}}$ & $\frac{20.05^{ \pm 6,13}}{397,6^{ \pm 30,2}}$ & $\frac{02.09^{ \pm 4,4}}{2560^{ \pm 77,5}}$ \\
\hline $\begin{array}{l}\text { J. ailantifolia var. } \\
\text { cordiformis }\end{array}$ & $\frac{07.04^{ \pm 3,5}}{76,2^{ \pm 23,2}}$ & $\frac{08.05^{ \pm 5,4}}{377,8^{ \pm 16,7}}$ & $\frac{12.05^{ \pm 6,1}}{371,1^{ \pm 16,3}}$ & $\frac{15.05^{ \pm 7,1}}{376,5^{ \pm 54,1}}$ & $\frac{21.05^{ \pm 6,1}}{398,2^{ \pm 31,1}}$ & $\frac{02.09^{ \pm 8,5}}{2560^{ \pm 7,1}}$ \\
\hline \multicolumn{7}{|c|}{ Атлантико-Північноамериканська флористична область } \\
\hline J. nigra & $\frac{15.04^{ \pm 7,0}}{370,4^{ \pm 11,3}}$ & $\frac{12.05^{ \pm 7,7}}{381,0^{ \pm 21,1}}$ & $\frac{18.05^{ \pm 6,1}}{420,3^{ \pm 23,2}}$ & $\frac{23.05^{ \pm 6,5}}{422,2^{ \pm 22,7}}$ & $\frac{28.05^{ \pm 6,3}}{430,1^{ \pm 41,3}}$ & $\frac{12.09^{ \pm 3,3}}{2675^{ \pm 8,5}}$ \\
\hline J. cinerea & $\frac{06.04^{ \pm 6,1}}{75,3^{ \pm 34,2}}$ & $\frac{10.05^{ \pm 6,1}}{397,4^{ \pm 14,6}}$ & $\frac{20.05^{ \pm 6,1}}{398,1^{ \pm 34,1}}$ & $\frac{24.05^{ \pm 5,1}}{407,1^{ \pm 13,1}}$ & $\frac{29.05^{ \pm 6,3}}{434,5^{ \pm 44,4}}$ & $\frac{30.09^{ \pm 8,7}}{2810^{ \pm 7,6}}$ \\
\hline \multicolumn{7}{|c|}{ Мадреанська флористична область } \\
\hline J. major & $\frac{25.04^{ \pm 3,5}}{390,4^{ \pm 10,5}}$ & $\frac{23.05^{ \pm 5,1}}{396,2^{ \pm 14,6}}$ & $\frac{25.05^{ \pm 6,1}}{407,2^{ \pm 12,8}}$ & $\frac{30.05^{ \pm 6,5}}{440,3^{ \pm 44,1}}$ & $\frac{06.06^{ \pm 6,4}}{471,1^{ \pm 12,2}}$ & $\frac{26.09^{ \pm 2,5}}{2770^{ \pm 8,5}}$ \\
\hline J. microcarpa & $\frac{17.04^{ \pm 8,5}}{363,7^{ \pm 12,2}}$ & $\frac{23.05^{ \pm 6,6}}{399,3^{ \pm 12,7}}$ & $\frac{28.05^{ \pm 6,1}}{412,1^{ \pm 20,1}}$ & $\frac{03.06^{ \pm 6,4}}{450,7^{ \pm 26,6}}$ & $\frac{08.06^{ \pm 6,5}}{496,1^{ \pm 24,4}}$ & $\frac{22.09^{ \pm 3,1}}{2370^{ \pm 25,0}}$ \\
\hline
\end{tabular}

У рослин з Атлантико-Північноамериканської флористичної області набрякання вегетативних бруньок спостерігається $08.04^{ \pm 10,5}$ (J. cinerea) за суми ефективних температур 88, $1^{ \pm 9,6}$. Розкривання вегетативних бруньок зафіксовано $02.05^{ \pm 9,5}$ за суми позитивних температур $330,4^{ \pm 7,3}$.

Рослини Мадреанської флористичної області вступають у період вегетації $08.04^{ \pm 10,5}$ (J. microcarpa) за суми ефективних температур $88,1^{ \pm 9,6}$. Розкривання вегетативних бруньок зафіксовано $02.05^{ \pm 9,5}$ за суми ефективних температур $330,4^{ \pm 7,3}$.

Набрякання генеративних бруньок зафіксовано спочатку у рослин з Ірано-Туранської флористичної області J. regia f. ftrtillis $\left(06.04^{ \pm 5,5}\right)$ за суми ефективних температур $71,1^{ \pm 7,5}$. Пізніше від всіх дослідних видів ця фенологічна фаза настає у рослин з Мадреанської флористичної області - J. major $\left(25.04^{ \pm 3,5}\right)$ за суми ефективних температур $390,4^{ \pm 10,5}$.

Розкривання генеративних бруньок усіх дослідних рослин спостерігається через 3,5-4 тижні після набрякання і відбувається спочатку у рослин з Японо-Китайської флористичної області $\left(03.05^{ \pm 7,1}\right)-J$. mandshuri$c a$, за суми ефективних температур $350,1^{ \pm 21,1}$. У рослин 3 Мадреанської флористичної області (J. major, J. microcarpa) ця фенологічна фаза настає $23.05^{ \pm 5,1}$ за більшої суми ефективних температур.

За період фенологічних спостережень початок цвітіння (див. табл. 2) відбувалось у Східноазійських видів (J. mandshurica) $07.05^{ \pm 6,1}$ за суми ефективних температур 361,1 $1^{ \pm 32,2}$. Рослини 3 Мадреанської флористичної області починають цвісти пізніше від усіх дослідних рослин - 25.05 ${ }^{ \pm 6,1}$ (J. major) за суми ефективних температур $407,2^{ \pm 12,8}$. Завершення цвітіння спочатку спостерігається у рослин зі Східноазійської флористичної області (J. mandshurica) $19.05^{ \pm 6,2}$ за суми ефективних температур 401,2 265,1 . Пізніше всіх дослідних видів завершення фази цвітіння відбувається у рослин з Мадре- анської флористичної області (J. microcarpa) $08.06^{ \pm 6,5}$ за суми ефективних температур $496,1^{ \pm 24,4}$.

На кожній рослині чоловічі і жіночі квітки розкриваються не одночасно, одні раніше, а інші пізніше, але тоді, коли на протоандрічних рослинах розкриваються чоловічі, одночасно на протогінічних розкриваються жіночі квітки.

Треба зазначити, що початок росту пагонів усіх дослідних видів щорічно розпочинається після завершення фази цвітіння. Ріст зав'язі усіх дослідних видів починається через 3-5 діб після завершення цвітіння.

Достигання плодів спочатку спостерігається у рослин Східноазійської флористичної області (див. табл. 2) - наприкінці третьої декади серпня (J.mandshurica) за суми ефективних температур $+24300^{ \pm 5,1}{ }^{\circ} \mathrm{C}$.

Достигання плодів у рослин 3 Атлантико-Північноамериканської флористичної області спостерігається 3 початку другої декади вересня $12.09^{ \pm 3,3}(\mathrm{~J}$. nigra) за суми ефективних температур $2675^{ \pm 6,4}{ }^{\circ} \mathrm{C}$. У рослин з Мадреанської флористичної області достигання плодів відбувається на початку третьої декади вересня.

Підтвердились літературні дані про те, що жіночі суцвіття у верхівкових бруньках формуються після завершення росту пагонів (табл. 3). За зовнішнім виглядом вони не відрізняються від вегетативних бруньок (Tyzh \& Antonyuk, 1984). Так, завершення росту пагонів спочатку спостерігається у рослин з Ірано-Туранської флористичної області $20.06^{ \pm 3,5}$ (J. regia f. fertillis) за суми ефективних температур 1375,2 $2^{ \pm 25,5}$ (див. табл. 1). У рослин з Японо-Китайської флористичної області ця фенологічна фаза настає пізніше ( $J$. ailantifolia)$04.08^{ \pm 3,8}$ за суми ефективних температур $2280,2^{ \pm 32,8}$.

Завершення періоду вегетації дослідних рослин пов'язане 3 переходом середньодобових температур нижче ніж $+5^{\circ} \mathrm{C}$. У цей період представники роду Juglans поступово входять у стан глибокого спокою, зовнішніми ознаками якого є зміна забарвлення листків та його природне опадання. 
Початок осіннього забарвлення листків спочатку зафіксовано у рослин зі Східноазійської (Японо-Китайської) флористичної області $28.08^{ \pm 9,5}$ (J.mandshurica) за суми ефективних температур $2430^{ \pm 6,5}{ }^{\circ} \mathrm{C}$. Найпізніше, 3 усіх дослідних видів, ця фаза настає у рослин з Мадреанської флористичної області (J. major) $15.09^{ \pm 6,5}$ за суми ефективних температур $2705,1^{ \pm 60,4}$.

Табл. 3. Терміни закладання жіночих бруньок видів роду Juglans та суми ефективних температур на цей період (Київ, 2015-2018 рр.).

\begin{tabular}{|c|c|c|c|c|c|c|c|c|}
\hline \multirow{2}{*}{ Вид, форма } & \multicolumn{4}{|c|}{ Рік спостережень } \\
\cline { 2 - 8 } & \multicolumn{2}{|c|}{2015} & \multicolumn{2}{|c|}{2016} & \multicolumn{3}{|c|}{2017} & \multicolumn{2}{c|}{2018} \\
\cline { 2 - 8 } & Дата & $t_{e \phi}$ & Дата & $t_{e \phi}$ & Дата & $t_{e \phi}$ & Дата & $t_{e \phi}$ \\
\hline J. microcarpa & 28.07 & 2300,2 & 29.07 & 2320,0 & 25.07 & 2250,0 & 30.07 & 2255,7 \\
\hline J. nigra & 30.07 & 2330,1 & 28.07 & 2300,1 & 23.07 & 2232,2 & 02.08 & 2285,0 \\
\hline J. major & 28.07 & 2300,2 & 29.07 & 2320,0 & 25.07 & 2250,0 & 30.07 & 2255,7 \\
\hline J. cinerea & 28.07 & 2300,2 & 28.07 & 2300,1 & 25.07 & 2250,0 & 26.07 & 2230,1 \\
\hline J.ailantifolia var. cordiformis & 25.07 & 2270,0 & 23.07 & 2220,4 & 23.07 & 2232,2 & 22.07 & 2220,4 \\
\hline J. ailantifolia & 05.08 & 2270,0 & 25.07 & 2260,1 & 07.08 & 2290,0 & 24.07 & 2260,1 \\
\hline J. mandshurica & 25.07 & 2270,0 & 25.07 & 2260,1 & 23.07 & 2232,2 & 22.07 & 2250,0 \\
\hline J. regia & 15.07 & 2186,4 & 15.07 & 2180,0 & 20.07 & 2160,0 & 18.07 & 2200,0 \\
\hline J. regiaf.fertillis & 20.06 & 1375,0 & 25.06 & 1440,0 & 23.06 & 1420,0 & 20.06 & 1320,1 \\
\hline
\end{tabular}

Листопад (див. табл. 1) (кінець вегетації) спочатку спостерігається у рослин Східноазійської (Японо-Китайської) флористичної області, в середньому $12.09^{ \pm 3,7}$ за суми ефективних температур $+2675,4^{ \pm 105,65 ~}{ }^{\circ} \mathrm{C}$. У рослин з Мадреанської флористичної області листопад настає пізніше від усіх дослідних видів в середньому $22.09^{ \pm 6,7}$ за суми ефективних температур $+2340,4^{ \pm 77,2}{ }^{\circ} \mathrm{C}$.

Як видно 3 табл. 1 і 2, терміни настання фенологічних фаз, які відображують сезонний розвиток, варіюють незначно між рослинами однієї флористичної області. Деякі показники значно варіюють між рослинами різних флористичних областей походження.

За період фенологічних спостережень пізньовесняний заморозок 2017 р. (30.05) припав на фазу цвітіння i зав'язування плодів, що призвело до загального зменшення врожайності усіх рослин (3-5 балів) порівняно 3 роками досліджень (4-6 балів) за шкалою Каппера, коли пізньовесняних заморозків не було. Найбільший врожай у 2017 р. було зафіксовано у рослин J. regia, J. regia f. fertillis (5 балів), а найменший (2 бали) - у рослин $J$. microcarpa. Ранньоосінній заморозок 2015 p. (08.10) не завдав шкоди, бо припав на період переходу дослідних рослин у стан спокою. За період досліджень періодичності плодоношення не зафіксовано, урожай щорічний.

Табл. 4. Тривалість вегетаційного періоду видів роду Juglans в умовах Лісостепу України за період 1960-1969 рр.; 2015-2018 рр.

Вид, різновид, форма \begin{tabular}{|c|c|}
\multicolumn{2}{c}{ Період досліджень } \\
\hline 1960-1969 рр. & $2015-2018$ pp. \\
\hline \multicolumn{2}{|c|}{ Кількість днів } \\
\hline
\end{tabular} Ірано-Туранська флористична область

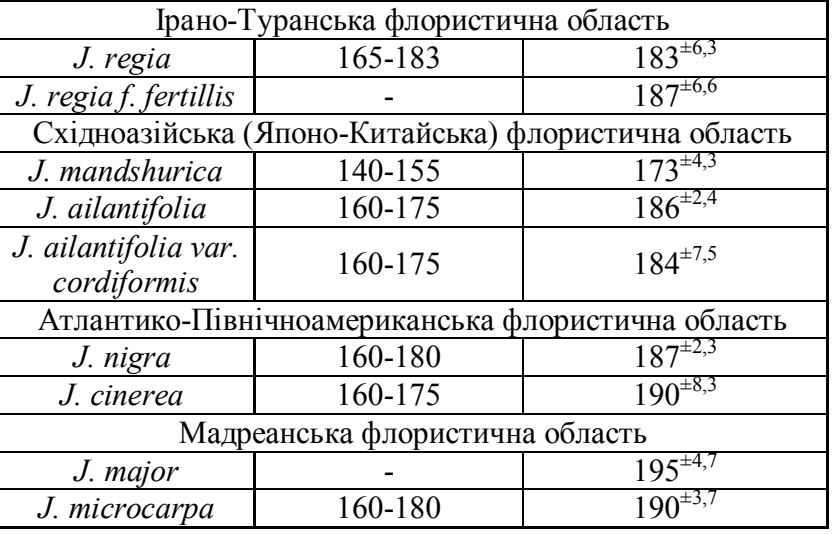

Фенологічні спостереження за рослинами Juglans, які здійснив Гришко-Богменко у 1960-1969 рр., показа- ли, що тривалість вегетації дослідних рослин була коротшою і становила 140-183 дні.

Дослідження, проведені у період з 2015-2018 рр., показали, що тривалість вегетаційного періоду рослин Juglans збільшилась, порівняно з даними середини ХХ ст., і становить 173-195 днів, що відповідає тривалості вегетаційного періоду в регіоні інтродукції (табл. 4).

За результатами досліджень побудовано феноспектр (рисунок), на якому відображено основні фази сезонного розвитку рослин роду Juglans.

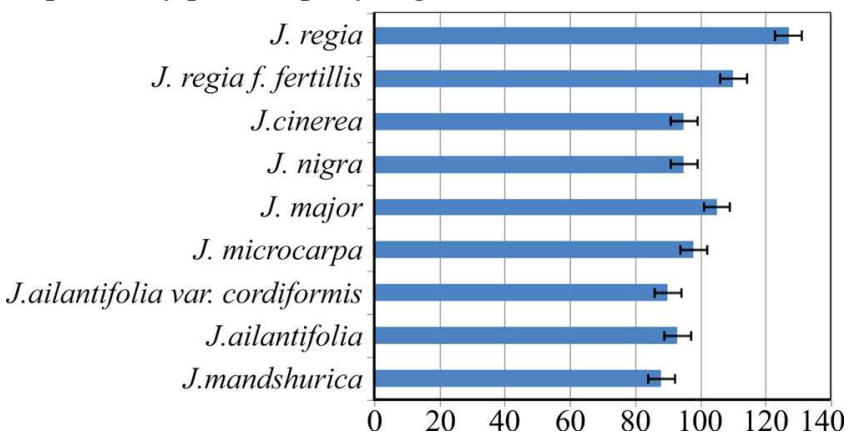

Рисунок. Феноспектр сезонного розвитку представників роду Juglans (середні значення даних за 2015-2018 рр.), кількість днів наведено від 1 березня

Висновки. Порівняння даних сезонних ритмів видів роду Juglans, які виконав Гришко-Богменко у 19601969 pp., і сучасних досліджень показало, що тривалість вегетації дослідних рослин збільшилась. Встановлено, що в умовах Лісостепу першим починає вегетувати $J$. mandshurica, потім $J$. regia $f$. fertillis, J. regia, J. ailantifolia var. cordiformis, J. ailantifolia i J. cinerea; ocтанніми - J. microcarpa, J. nigra, J. major. Тривалість вегетаційного періоду рослин Juglans становить 173195 днів. Найбільш короткий вегетаційний період виявився у J. mandshurica (173 дні). Найтриваліший вегетаційний період зафіксовано у $J$. major (195 днів). У рослин $J$. microcarpa, J. nigra, J. major вегетаційний період зсунувся до осінньо-зимового сезону.

Установлено, що настання кожної фази вегетації залежить від потрібного, генетично визначеного, інтервалу часу та суми ефективних температур. Фенологічні ритми вивчених видів відповідають вегетаційному періоду Лісостепу України, тобто досліджені види перспективні для широкого використання у цій зоні. 


\section{References}

1. Aboimova, A. N., \& Polyakov, A. K. (2014). Sezonnoye razvitiye $i$ ustoychivost $k$ zime Juglans regia L. na yugo-vostoke Ukrainy: mezhdunarodnaya nauchno-prakticheskaya konferentsiya Lisove i sadovo-parkove khozyaystvo KhKhI veka: aktualnyye problemy i perspektivy", (Kiyev, 13-14 avgusta 2014 y.), 175 p. [In Russian].

2. AMS Council. (2012). American Meteorological Society (AMS) Information Statement on Climate Change: journal. Boston, Massachusetts, USA: AMS, 20 August.

3. Bulygin, N. Ye. (1976). Dendrologiya. Fenologicheskiye nablyudeniya nad listvennymi drevesnymi rasteniyami: Posobiye po provedeniyu ucheb.-nauch. issledovaniy dlya studentov lesokhoz. fak. Lviv: Riolta, 70 p. [In Russian].

4. Fokina, N. V., Ligayeva, N. A., \& Busygina, L. V. (2013). Dinamika klimata i izmeneniye fenologicheskikh sezonov goda zapovednika "Stolby". Vestnik KGPU im. V. P. Astafyeva, 2(24), 228-231. [In Russian].

5. Grishko-Bogmenko, B. K. (1969). Biologicheskiye osobennosti vidov roda Juglans v usloviyakh lesostepi Ukrainy. Abstract of Candidate Dissertation for Biological Sciences. Kiyev, 20 p. [In Russian].

6. Jackson, R., \& Jenkins, A. (2012). Vital signs of the planet: global climate change and global warming: uncertainties: journa. Earth
Science Communications Team at NASAs Jet Propulsion Laboratory - California Institute of Technology, 17 November.

7. Kapper, V. G. (1930). Ob organizatsii yezhegodnykh sistematicheskikh nablyudeniy nad plodonosheniyem drevesnykh porod: $T r$. po lesnomu opytnomu delu. Leningrad, 8, 103-139. [In Russian].

8. Metodika. (1975). Metodika fenologicheskikh nablyudeniy v botanicheskikh sadakh SSSR. Moscow: Izd-vo AN SSSR, 27 p. [In Russian].

9. Pogoda Kiyev. (2014-2019). Yelektronniy resurs. Retrieved from: http://prognoz-pogoda.com/arhiv/kyiv. [In Russian].

10. Shnelle, F. (1961). Fenoglogiya rasteniy: Monografiya. Leningrad: Gidrometizdat, 259 p. [In Russian].

11. The Plant List. (2019). Retrieved from: https://www.theplantlist.org/

12. Tyzh, P. M., \& Antonyuk, N. M. (1984). Skoroplodnaya $i$ obyknovennaya formy orekha gretskogo. Kyiv: Nauk. dumka, 136 p. [In Russian].

13. World Plant. (2019). Retrieved from: https://www.worldplants.ca/

14. Zaitsev, G. N. (1981). Fenologiya drevesnykh rasteniy. Moscow: Nauka, 120 p. [In Russian].

15. Zaytsev, G. N. (1991). Matematicheskiy analiz biologicheskikh dannykh: Monografiya. Moscow: Nauka, 184 p. [In Russian].

M. M. Gryshko National Botanical Garden, NAS Ukraine, Kyiv, Ukraine

\section{FEATURES OF SEASONAL DEVELOPMENT OF SPECIES OF THE GENUS JUGLANS L. IN THE CONDITIONS OF THE KYIV POLISSYA}

The features of seasonal development of plants of the genus Juglans in the conditions of Kyiv Polissya in 2015-2018 yy. It was found that in Kyiv Polissya conditions $J$. mandshurica, J. regia f. fertillis, J. regia, and J. ailantifolia var cordiformis first begin to vegetate, the latter are J. microcarpa, J. nigra, and J. major. During the period of phenological observations, the first phase of flowering took place in East Asian species (J. mandshurica) $07.05^{ \pm 6.1}$ for the sum of effective temperatures of $361.1^{ \pm 32.2}$. Plants from the Madrean floristic region begin to bloom later than all experimental plants $-25.05^{ \pm 6.1}$ (J. major) for the sum of effective temperatures of 407.2 $2^{ \pm 12.8}$. During the period of phenological observations, the first phase of flowering occurs in East Asian species (J. mandshurica) $07.05^{ \pm 6.1}$ for the sum of effective temperatures of $361.1^{ \pm 32.2}$. Plants from the Madrean floristic region begin to bloom later than all experimental plants $-25.05^{ \pm 6.1}$ (J. major) for the sum of effective temperatures of $407.2^{ \pm 12.8}$. Flowering termination is initially observed in plants from the East Asian floristic region (J. mandshurica) $19.05^{ \pm 6.2}$ for sums of effective temperatures $401.2^{ \pm 65.1}$. Later in all experimental species, flowering phase completion occurs in plants from the Madrean floristic region (J. microcarpa) $08.06^{ \pm 6.5}$ for the sum of effective temperatures 496.1 $1^{ \pm 24.4}$. Fruit maturation is first observed in East Asian floristic plants-at the end of the third decade of August ( $J$. mandshurica) due to effective temperatures of $+24300^{ \pm 5.1}{ }^{\circ} \mathrm{C}$. Fruit maturation in plants from the Atlantic-North American floristic region has been observed since the beginning of the second decade of September $-12.09^{ \pm 3.3}(\mathrm{~J}$. nigra) with the sum of effective temperatures of $2675^{ \pm 6.4}{ }^{\circ} \mathrm{C}$. In plants from the Madrean floristic region, fruit maturation occurs at the beginning of the third decade of September. The beginning of autumn leaf color was first recorded in plants from the East Asian (Japanese-Chinese) floris-

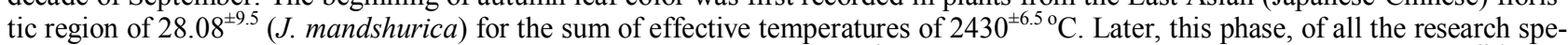
cies, occurs in plants from the Madrean floristic region (J. major) $15.09^{ \pm 6.5}$ for the sum of effective temperatures of $2705.1^{ \pm 60.4}$. November (end of vegetation) is first observed in plants of the East Asian (Japanese-Chinese) floristic region, with an average of $12.09^{ \pm 3.7}$ for the sum of effective temperatures $+2675.4^{ \pm 105.65}{ }^{\circ} \mathrm{C}$. In plants of the Madrean floristic region, November comes later than all research species on average $22.09^{ \pm 6.7}$ for the sum of effective temperatures $+2780.4^{ \pm 77.2}{ }^{\circ} \mathrm{C}$. The length of the growing season of Juglans plants is 173-195 days, which corresponds to the growing season in the region of introduction and they are promising for mass cultivation.

Keywords: phenological phases; sum of effective temperatures; vegetative organs, generative organs, vegetation period. 